\title{
On a possibility of predicting porcine meat quality from blood biochemical tests
}

\author{
Maria KUC̄WIN-PODSIADEY \\ Institute for Breeding and Technology of Animal Production, \\ Department of Pig and Horse Breeding, \\ Academy of Agriculture, Szczecin, Poland
}

\begin{abstract}
Summary
Two experimental groups of Polish Large White pigs were tested : the animals of the first group (I) consisting of 56 pigs ( 29 gilts and 27 hogs) were slaughtered when weighing $101 \mathrm{~kg}$, and those in the other (II) group (58 gilts) were slaughtered when weighing $87 \mathrm{~kg}$. Chemical analyses involving determinations of alanine aminotransferase (ALAT) and asparagine aminotransferase (AspAT) activities as well as P-RNA ${ }^{\circ}{ }^{\circ}$ (P-RNA - phosphorus of RNA) leuco- and lymphocytes were carried out in the 4-, 6-, and 7-month-old pigs of group I, and in the 4- and 6-month-old ones of group II. Blood serum $\mathrm{Cu}$ and $\mathrm{Mg}$ contents were determined ad above in group II and in the 4-month-old pigs in group I.

The objective of the work presented was to find a relationship between the blood biochemical parameters studied and porcine meat quality indices for various weights at slaughter (101 and $87 \mathrm{~kg}$ ).

The following conclusions were drawn :

1. Of the blood biochemical parameters and meat quality indices tested, it is only the meat rigor mortis that is significantly influenced by sex, a highly significant difference in favour of hogs being found.

2. From the pig breeder's point of view, the most valuable blood biochemical parameters are : blood serum AspAT, $\mathrm{Cu}$, and $\mathbf{M g}$, and peripheral blood P-RNA $/ 10^{9}$ leucocytes, all of them showing a statistically significant correlation with meat quality indices as early as in the 4-month-old pigs.

3. A phenotypic correlation does not suffice to state with certainty that one character in a definite way influences another ; therefore - in order to assess the relationships involved more definitely - it is necessary to have a more abundant study material as well as to calculate genetic correlations between the blood biochemical parameters and meat quality indices.
\end{abstract}

\section{1. - Introduction}

Pig breeding activities are focused mainly on increasing the meat yield, with a due consideration being at the same time given to retaining a good quality of meat produced. However, a decrease in meat quality accompanying the increase in quan- 
titative yield indices is being observed by the breeders. An opinion has recently gained a wide acceptance that more fleshy pigs which grow faster and utilise their food more efficiently produce meat of a poorer quality (Ender \& Pfeiffer, 1974; DUNIEC et al., 1975).

Therefore a need arises to look for new, possibly simple methods facilitating an intravitally qualitative and quantitative assessment of meat. There is a body of data pointing towards a relation existing between pig fleshiness and meat utility indices on the one hand, and blood biochemical parameters on the other, the examples of the latter being provided by asparaginate and alanine aminotransferase (AspAT) and (ALAT) respectively activities (Suskov, 1971), P-RNA content in blood (Petrenko, 1969), P-RNA content in blood leuco- and lymphocytes (KoćwIN, 1974).

The work presented was aimed at seeking a connection between certain blood biochemical parameters (AsPAT, ALAT in blood serum P-RNA in leuco- and lymphocytes of blood, $\mathrm{Cu}$ and $\mathrm{Mg}$ contents in blood) as determined in various age groups and quality indices of porcine meat at various weights.

\section{2. - Material and methods}

The materials studied comprised porcine peripheral blood leucocytes, lymphocytes, and serum as well as carcasses.

Two experimental groups of Polish Large White (wbp) pigs were studied. One group (I), consisting of 56 randomly selected individuals (29 gilts and 27 hogs) of uniform age ( \pm 3 days) was supplied by the Experimental Breeding Farm (EBF) at Kolbacz; the animals were slaughtered when weighing $101 \pm 5.3 \mathrm{~kg}$.

The other group (II), supplied by the Pig Slaughter Quality Control Station (PSQCS) at Melno, consisted of 58 individuals (all females) slaughtered when weighing $87 \mathrm{~kg}$.

The experimental animals were kept under the same conditions in terms of location and diet (individual feeding):

- group I : from 26.5 to $101 \mathrm{~kg}$ body weight;

- group II : from 30 to $87 \mathrm{~kg}$ body weight.

Blood samples were taken from the anterior vena cava in the morning (before feeding) at the age of 4,6 and 7 months, and at 4 and 6 months in groups I and II, respectively.

Chemical analyses involving determinations of enzymatic activities (AspAT and ALAT) in blood serum of P-RNA concentration per $10^{*}$ leucocytes and lymphocytes were performed at age of 4,6 and 7 months in group 1 , and at 4 and 6 months in group II, while serum $\mathrm{Cu}$ and $\mathrm{Mg}$ contents were determined twice (at 4 and 6 mo.) and once (at $4 \mathrm{mo}$.) in groups II and I, respectively.

All the analyses were made in triplicate. 
The AspAT and ALAT activities were determined using the technique by Reitman \& Frankel (1956) and expressed in units required by the technique.

Leucocytes were isolated from blood using fractional sedimentation (WALTER, 1970), whereas a steelon gauze column was applied to isolation of lymphocytes (WAI.TER, 1970); numbers of leucocytes obtained per $1 \mathrm{~mm}^{3}$ were converted to numbers per a blood sample volume taken.

The procedures associated with isolating the P-RNA containing fraction of cell homogenate were performed according to SCHMidT \& TANNHAuser (1945). Leucocyte and lymphocyte ribonucleic acids were determined spectrophotometrically according to TSanev \& Markov (1960). The amount of P-RNA per $10^{9}$ cells was calculated from the formulae given by these authors as described by WALTER (1970).

Blood serum $\mathrm{Cu}$ and $\mathrm{Mg}$ contents were determined using absorption spectrophotometry on a Pye Unicam SP 1900 spectrophotometer, following the manufacturer's instructions. The results were expressed in $\mu \mathrm{g} / 100 \mathrm{ml}$ serum $(\mathrm{Cu})$ and $\mathrm{mg}$ p. $100(\mathrm{Mg})$.

The following parameters were used for the meat quality assessment after slaughter : $\mathrm{pH}$ after $45 \mathrm{~min}$., $\mathrm{pH}$ after 24 hours, rigor mortis and colour.

$\mathrm{pH}$ was measured with a combined electrode in the longissimus dorsi muscle.

Ham rigor mortis was determined using an rigorometer apparatus, according to Vos and Sybesma (1971).

The longissimus dorsi muscle colour for group I was determined on a Specol spectrophotometer furnished with an $\mathrm{Rd} / \mathrm{O}$ reflectance attachment at $680 \mathrm{~nm}$, following OCKERMAN \& CAHIL (1969). For group II meat colour was measured, 24 hours after slaughter, on a Göfo apparatus.

Statistical significance of differences between sexes with respect to the characters studied, i.e., AspAT and ALAT activities, serum $\mathrm{Cu}$ and $\mathrm{Mg}$ contents, P-RNA/ $10^{4}$ leuco- and lymphocytes in peripheral blood, as well as meat quality indices $(\mathrm{pH}$, rigor mortis, and colour) was assessed from the formulae given by MUDRA (1958). Coefficients of correlation between the blood biochemical indices, determined for various ages in each group, and the meat quality ones were calculated according to procedures described by SNEDECOR (1956).

\section{3. - Results and discussion}

The group of biochemical parameters under consideration consisted of aminotransferase enzymes in blood serum, ribonucleic acids in peripheral blood leuco- and lymphocytes, all of them participating in protein biosynthesis, and $\mathrm{Cu}$ and $\mathrm{Mg}$ in blood serum. According to DAvidson (1972), $\mathrm{Cu}$ does take part in protein biosynthesis, however the mechanism of its activity is being, though, poorly known; on the other hand, $\mathrm{Mg}$ in the presence of an appropriate starter and influenced by a polymerase (nucleotidiltransferase) takes an active part in nucleic acids biosynthesis during triphosphate polymerisation to DNA and RNA. 


\section{TaBle 1}

Mean values of $87 \mathrm{~kg}$ pig meat quality indices and blood biochemical parameters (group II)

Valeurs moyennes des indices pour des porcs de $87 \mathrm{~kg}$ et paramètres biochimiques sanguins (groupe II)

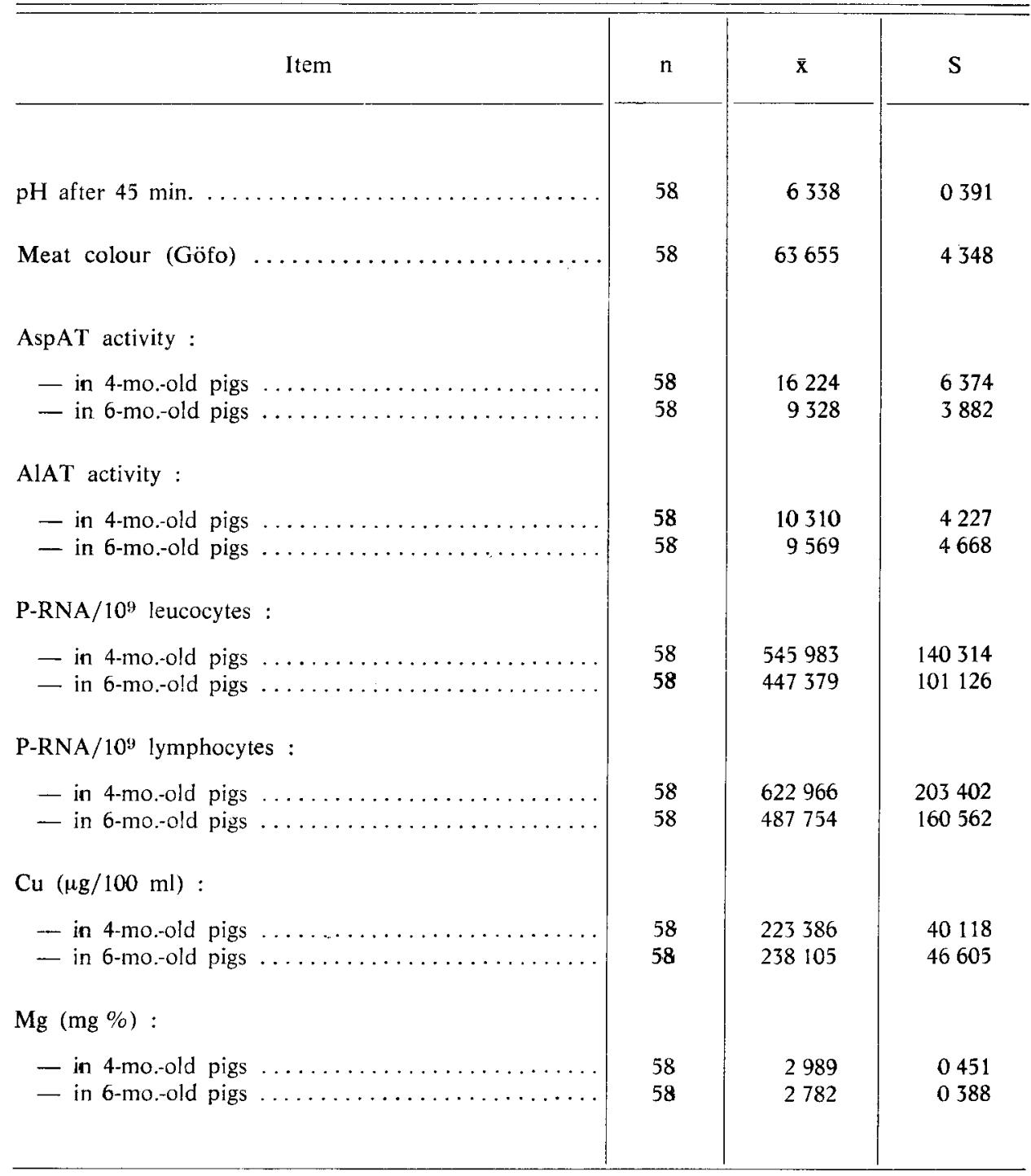

$\mathrm{n}$ : Number of individuals tested.

$\overrightarrow{\mathbf{x}}$ : Arithmetic mean.

S : Standard deviation. 
TABLE 2

Mean values of $101 \mathrm{~kg}$ pig meat quality indices and blood biochemical parameters (group I)

Valeurs moyennes des indices pour des porcs de $101 \mathrm{~kg}$ et paramètres biochimiques sanguins (groupe I)

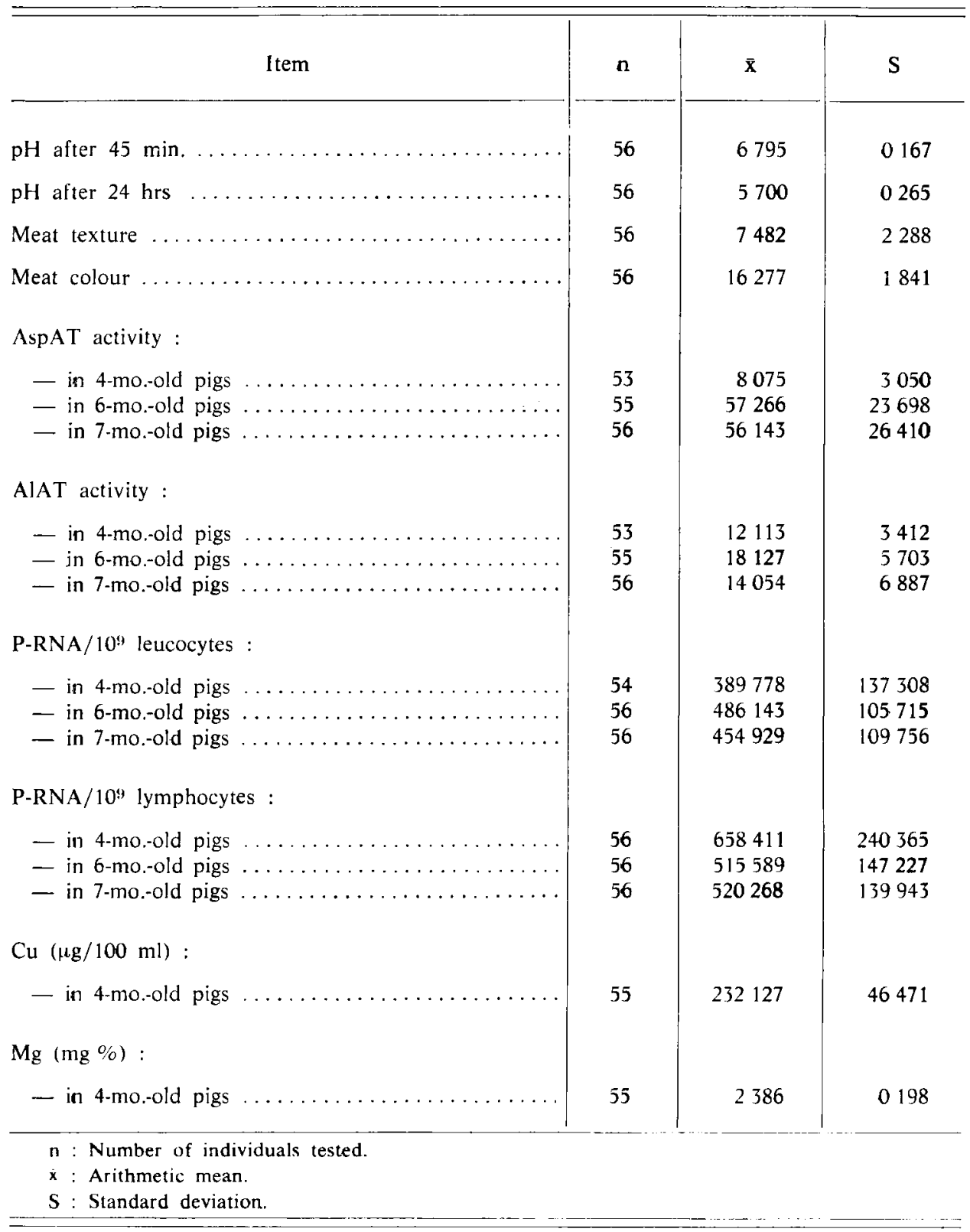


The relatively high variability shown by the aminotransferases studied (tables 1 and 2) was also observed by Suskov (1971) who found high variabilities of serum AspAT and ALAT in pigs of $40-100 \mathrm{~kg}$ body weight, and by DerevinskIJ (1970) who - when analysing activities of these enzymes in blood serum of various pig breds showed a high breed-dependent variability in both ALAT and AspAT activities. A high (exceeding 30 p. 100) variability of this parameter was observed in other domestic animals as well : poultry (Kolatay, 1966) and cattle (GuszkiEwicz, 1972). The case of coefficients of variation calculated for the peripheral blood leucoand lymphocytes P-RNA contents in various age groups (tables 1 and 2 ) is slight different. Against the background of the literature data this parameter exhibits a relatively low variability (21.7-36.5 p. 100). At the same time, a marked decline in the coefficients of variation for the above indices is observed with age of the experimental animals. A decreased variability is observed in the 7-month-old pigs (ribonucleic acid contents in porcine blood leuco- and lymphocytes level off ; KoćwIN, 1974, 1976). Similar, although slightly higher coefficients of variation were reported by ZIELINSKA (1973) for ribonucleic acids in cattle blood (c.v. of 41.5-44.6 p. 100), GLEN (1967) for ribonucleic acids in human blood (32 p. 100), and KoćWrN (1974, 1976) for RNA in leuco- and lymphocytes of 4-, 6-, and 8-month-old pigs (about 45 p. 100).

TABLE 3

Levels of significance for differences between mean values of blood biochemical parameters and meat quality indices in males and females of $101 \mathrm{~kg}$ pigs

Taux de signification concernant les différences entre les valeurs moyennes des paramètres biochimiques sanguins et les indices de qualité de la viande chez les mâles et les femelles de $101 \mathrm{~kg}$

\begin{tabular}{|c|c|c|c|}
\hline Item & Age (months) & $\mathrm{Sd}$ & $\mathrm{d}$ \\
\hline AspAT activity & $\begin{array}{l}4 \\
6 \\
7\end{array}$ & $\begin{array}{l}0.842 \\
6.420 \\
7.121\end{array}$ & $\begin{array}{r}0.673 \\
-\quad 5.241 \\
2.350\end{array}$ \\
\hline ALAT activity .... & $\begin{array}{l}4 \\
6 \\
7\end{array}$ & $\begin{array}{l}0.941 \\
1.548 \\
1.846\end{array}$ & $\begin{array}{r}-0.846 \\
-\quad 1.071 \\
1.606\end{array}$ \\
\hline P-RNA/ $10^{9}$ leucocytes & $\begin{array}{l}4 \\
6 \\
7\end{array}$ & $\begin{array}{l}37.410 \\
27.603 \\
29.622\end{array}$ & $\begin{array}{r}36.660 \\
-53.078 \\
1.078\end{array}$ \\
\hline P-RNA $/ 10^{9}$ lymphocytes $\ldots$ & $\begin{array}{l}4 \\
6 \\
7\end{array}$ & $\begin{array}{l}64.651 \\
39.650 \\
37.769\end{array}$ & $\begin{array}{r}39.485 \\
-19.174 \\
2.595\end{array}$ \\
\hline 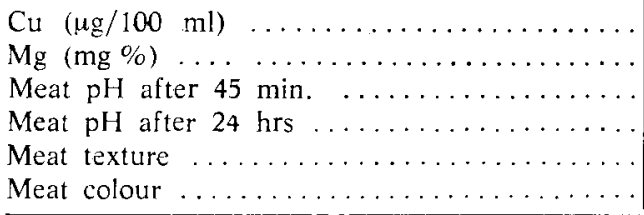 & $\begin{array}{l}4 \\
4\end{array}$ & $\begin{array}{r}12.511 \\
0.052 \\
0.045 \\
0.070 \\
0.515 \\
0.488\end{array}$ & $\begin{aligned}- & 14.493 \\
- & 0.093 \\
& 0.032 \\
& 0.093 \\
& 2.505^{* *} \\
- & 0.699\end{aligned}$ \\
\hline $\begin{array}{l}\mathrm{d}: \text { Difference between means }(q-\delta), \\
* * \text { Highly significant difference. } \\
\text { Sd : Empirical value calculated according to a }\end{array}$ & formula given by & Mudra, 1958. & \\
\hline
\end{tabular}


The observed spread of the P-RNA content values results presumably from the varying stage of blood cells maturity (DAVIDSON, 1972) and from altered leucocyte types circulating in blood (MURRAY, 1961; HARRIS, 1961).

When determining the level of significance for differences between mean values of the blood biochemical parameters in the 4-, 6-, and 7-month-old pigs, no effect of sex on the indices studied was found (table 3). This finding is corroborated by other papers, both with reference to the blood serum AspAT and ALAT (DEREVINSKIJ, 1970; KṓwIN \& PIEch, 1978) and to the peripheral blood leuco- and lymphocytes P-RNA (Kó̄WIN, 1974, 1976).

\section{TABLE 4}

Coefficients of correlation between blood biochemical parameters and meat quality indices in group I (101 kg pigs)

Coefficients de corrélation entre les paramètres biochimiques sanguins et les indices de qualité de la viande dans le groupe I (porcs de $101 \mathrm{~kg}$ )

\begin{tabular}{|c|c|c|c|c|c|c|}
\hline Item & $\mathrm{n}$ & $\begin{array}{c}\text { Age } \\
\text { (months) }\end{array}$ & $\begin{array}{c}\mathrm{pH} \\
\text { after } \\
45 \mathrm{~min} .\end{array}$ & $\begin{array}{c}\mathrm{pH} \\
\text { after } \\
24 \mathrm{hrs}\end{array}$ & $\begin{array}{l}\text { Meat } \\
\text { rigor } \\
\text { mortis }\end{array}$ & $\begin{array}{l}\text { Meat } \\
\text { colour }\end{array}$ \\
\hline AspAT activity & $\begin{array}{l}53 \\
55 \\
56\end{array}$ & $\begin{array}{l}4 \\
6 \\
7\end{array}$ & $\begin{array}{r}0.031 \\
0.110 \\
-0.093\end{array}$ & $\begin{array}{r}0.275^{*} \\
-0.019 \\
-0.101\end{array}$ & $\begin{array}{c}-0.278^{*} \\
-0.207 \\
0.030\end{array}$ & $\begin{array}{r}-0.283^{*} \\
-0.083 \\
-0.186\end{array}$ \\
\hline ALA'T activity & $\begin{array}{l}53 \\
55 \\
56\end{array}$ & $\begin{array}{l}4 \\
6 \\
7\end{array}$ & $\begin{array}{r}0.177 \\
0.090 \\
0.086\end{array}$ & $\begin{array}{r}0.084 \\
0.014 \\
0.071\end{array}$ & $\begin{array}{l}-0.244^{*} \\
-0.086 \\
-0.020\end{array}$ & $\begin{array}{r}-0.085 \\
0.065 \\
-0.093\end{array}$ \\
\hline P-RNA/10\% leucocytes . . & $\begin{array}{l}54 \\
56 \\
56\end{array}$ & $\begin{array}{l}4 \\
6 \\
7\end{array}$ & $\begin{array}{l}0.175 \\
0.111 \\
0.228\end{array}$ & $\begin{array}{l}0.286^{*} \\
0.064 \\
0.065\end{array}$ & $\begin{array}{r}0.142 \\
-0.227 \\
0.122\end{array}$ & $\begin{array}{r}-0.178 \\
-0.050 \\
-0.006\end{array}$ \\
\hline P-RNA/10" lymphocytes & $\begin{array}{l}56 \\
56 \\
56\end{array}$ & $\begin{array}{l}4 \\
6 \\
7\end{array}$ & $\begin{array}{l}0.114 \\
0.163 \\
0.054\end{array}$ & $\begin{array}{r}0.134 \\
0.181 \\
-0.074\end{array}$ & $\begin{array}{l}-0.141 \\
-0.118 \\
-0.106\end{array}$ & $\begin{array}{r}-0.099 \\
-0.083 \\
0.029\end{array}$ \\
\hline $\mathrm{Cu}(\mu \mathrm{g} / 100 \mathrm{ml})$ & 55 & 4 & 0.007 & 0.124 & -0.069 & 0.030 \\
\hline $\mathrm{Mg}(\mathrm{mg} \%)$ & 55 & 4 & -0.057 & -0.060 & -0.079 & 0.084 \\
\hline
\end{tabular}

$\mathrm{n}:$ Number of individuals.

* : Statistically significant coefficient.

Contrary to the general consensus as to a clear superiority of gilts when the quantity characters of meat produced are concerned, there are various opinions with respect to an effect of sex on meat quality. Some papers show no such effect to exist (MCGloughlin \& McGloughlin, 1975), while other authors reveal clearly-marked, statistically significant differences documented for $\mathrm{pH}$ and colour of meat of gilts and hogs, in favour of the latter (DuNiEC et al., 1975). 
The present studies failed to reveal any effect of sex upon $\mathrm{pH}$ and colour of meat. On the other hand, highly significant differences were found between ham meat rigor mortis of gilts and hogs (table 3), the hogs examined showing more favourable values of this parameter.

The analyses of the interrelationship between the blood biochemical characteristics and meat quality indices (tables 4 and 5) showed the serum AspAT and ALAT activities as well as P-RNA/ $10^{\prime \prime}$ leucocytes, determined in the 4-mo.-old to be significantly correlated with $\mathrm{pH}$ after 24 hours, meat colour, and ham rigor mortis for those animals reaching $101 \mathrm{~kg}$ when slaughtered (group I). The values of correlation coefficients obtained, positive for the correlation with $\mathrm{pH}$ and negative for those with meat colour and rigor mortis, were relatively low.

\section{TABLE 5}

Coefficients of correlation between blood biochemical parameters and meat $\mathrm{pH}$ colour in group /I $(87 \mathrm{~kg}$ pigs $)$

Coefficients de corrélation entre les paramètres biochimiques sanguins, le $\mathrm{pH}$ et la couleur de la viande dans le groupe II (porcs de $87 \mathrm{~kg}$ )

\begin{tabular}{|c|c|c|c|c|}
\hline Item & $n$ & $\begin{array}{c}\text { Age } \\
\text { (months) }\end{array}$ & $\begin{array}{c}\mathrm{pH} \\
\text { after } 45 \mathrm{~min} .\end{array}$ & Meat colour \\
\hline AspAT activity & $\begin{array}{l}58 \\
58\end{array}$ & $\begin{array}{l}4 \\
6\end{array}$ & $\begin{array}{r}0.015 \\
-0.023\end{array}$ & $\begin{array}{r}-0.028 \\
0.115\end{array}$ \\
\hline$\ldots \ldots \ldots \ldots \ldots$ & $\begin{array}{l}58 \\
58\end{array}$ & $\begin{array}{l}4 \\
6\end{array}$ & $\begin{array}{l}-0.181 \\
-0.095\end{array}$ & $\begin{array}{r}-0.183 \\
0.043\end{array}$ \\
\hline P-RNA/109 leucocytes & $\begin{array}{l}58 \\
58\end{array}$ & $\begin{array}{l}4 \\
6\end{array}$ & $\begin{array}{l}0.086 \\
0.304^{*}\end{array}$ & $\begin{array}{r}-0.133 \\
0.177\end{array}$ \\
\hline P-RNA/109 lymphocytes ... & $\begin{array}{l}58 \\
58\end{array}$ & $\begin{array}{l}4 \\
6\end{array}$ & $\begin{array}{l}0.074 \\
0.194\end{array}$ & $\begin{array}{c}-0.051 \\
0.250^{*}\end{array}$ \\
\hline $\mathrm{Cu}(\mu \mathrm{g} / 100 \mathrm{ml}) \ldots \ldots$ & $\begin{array}{l}58 \\
58\end{array}$ & $\begin{array}{l}4 \\
6\end{array}$ & $\begin{array}{l}0.240^{*} \\
0.178\end{array}$ & $\begin{array}{l}0.102 \\
0.102\end{array}$ \\
\hline $\mathrm{Mg}(\mathrm{mg} \%)$ & $\begin{array}{l}58 \\
58\end{array}$ & $\begin{array}{l}4 \\
6\end{array}$ & $\begin{array}{r}0.180 \\
-0.079\end{array}$ & $\begin{aligned} & 0.330^{*} \\
- & 0.155\end{aligned}$ \\
\hline
\end{tabular}

$\mathrm{n}$ : Number of individuals.

* : Statistically significant coefficient.

Of the blood biochemical parameters discussed, the AspAT activity proved most valuable as an index interrelated with all the quality indices tested. The ALAT activity, when assessed in the 4-mo.-old pigs, was found to be significantly correlated with ham rigor mortis only $(\mathrm{r}=\ldots 0.244, \mathrm{p}>0.05)$ while the $\mathrm{P}-\mathrm{RNA} / 10^{4}$ leucocytes showed a significant correlation with the longissimus dorsi muscle $\mathrm{pH}(\mathrm{r}=+0.286$, $\mathrm{p}>0.05$ ). 
The correlation coefficients obtained imply an increase in meat $\mathrm{pH}$, colour intensity, and improvement of rigor mortis to accompany any increase in the blood biochemical parameters studied.

The PSQCS batch of animals showed statistically significant positive correlations between P-RNA in leuco- and lymphocytes and $\mathrm{pH}$ after $45 \mathrm{~min}$, and meat colour in the 6-mo.-olds, as well as between the $\mathrm{Cu}$ and $\mathrm{Mg}$ contents and meat $\mathrm{pH}$ and colour in the 4-mo.-olds (Table 5).

The trends exhibited by the relationships between the biochemical and meat quality indices differed in the two groups of animals examined, which might have perhaps resulted from different conditions of living and slaughter and from different weights at slaughter (JANICKI, 1970).

Another question is the effect of various breeding stations providing animals for the studies on meat quality indices. As opposed to the EBF pigs, the PSQCS animals were bred in pigsties situated within the area covered by controlling activities of the Station.

So far there have been a few papers only dealing with the problem of possible relationships between the physiological characters discussed and what here thus precluding a more extensive comparison of the present results with those reported by other authors.

Owing to that reason, the comparison must be restricted only to the results of attempts to interrelate some enzyme activities and macroelements contents in blood serum and meat quality indices, mainly the after-slaughter $\mathrm{pH}$.

In their paper concerning relations between the contents of $\mathrm{K}, \mathrm{Na}, \mathrm{Ca}$, and $\mathrm{Mg}$, and the CPK and GOT activities in blood serum, and meat utility and $\mathrm{pH}$, Sidor \& KovaC (1972) presented statistically significant correlations between the parameters they compared.

The significant correlations obtained in the present work may indicate towards a relevant question of improving porcine meat quality without decreasing an optimal meat yield. It seems, however, that a more detailed assessment of the correlations considered (based on a more ample material and genetical relationships) would provide a more definite answer to the problem. A phenotypic relationship is not enough to claim a defined effect of one character upon another; the correlation coefficients obtained in this study are thus representative only of the population for which they have been evaluated.

\section{4. - Conclusions}

The following conclusions can be drawn from the results presented:

1. Highly significant differences with respect to hind ham rigor mortis were found between pig sexes in favour of hogs.

2. No effect of sex on the blood biochemical parameters (AspAT and ALAT activities, P-RNA/ $10^{\prime \prime}$ leuco- and lymphocytes, $\mathrm{Cu}$ and $\mathrm{Mg}$ contents in blood serum) and meat $\mathrm{pH}$ and colour was found. 
3. Significant coefficients of correlation were found to exist in the $101 \mathrm{~kg}$ pigs between the AspAT and ALAT activities, P-RNA/ $10^{9}$ leucocytes, as determined in the 4-mo.old pigs and pH $24 \mathrm{hrs}$ after slaughter, rigor mortis, and colour of meat. The correlation coefficients obtained imply an increase in meat $\mathrm{pH}$, colour intensity, and improvement of rigor mortis to accompany any increase in the blood biochemical parameters studied.

4. The P-RNA/10 leuco- and lymphocytes determined in the 6-mo-old pigs are significantly correlated with $\mathrm{pH}$ after $45 \mathrm{~min} .\left(\mathrm{r}=+0.304^{x}\right)$ and with meat colour $\left(r=+0.250^{x}\right)$.

5. Significant coefficients of correlation were found to exist in the $87 \mathrm{~kg}$ pigs between the serum $\mathrm{Cu}$ content in the 4-mo.-old animals and meat $\mathrm{pH}\left(\mathbf{r}=+0.240^{\mathrm{x}}\right)$, and between the serum $\mathrm{Mg}$ content and meat colour $\left(\mathrm{r}=0.330^{\mathrm{x}}\right)$.

6. A phenotypic correlation is not sufficient to conclude on a defined effect of one character upon another ; therefore, a more detailed assessment of those correlations calls for a more abundant study material and an investigation into genetic relationships between the blood biochemical parameters studied and meat quality indices.

Accepté pour publication en juin 1981.

\section{Résumé}

Indices biochimiques sanguins et caractéristiques de la qualité de la viande de porc

Cette étude a porté sur deux groupes expérimentaux de porcs de race Large White Polonais : un premier groupe de 56 animaux (29 truies et 27 mâles castrés) abattus au poids vif de $101 \mathrm{~kg}$, un deuxième groupe composé de 58 truies abattues au poids de $87 \mathrm{~kg}$. L'estimation des activités alanine aminotransférase (ALAT) et asparagine aminotransférase (AspAT) dans le sérum sanguin, et du taux de phosphore du RNA (P.RNA) dans les leucocytes était effectuée à trois reprises, aux âges de 4,6 et 7 mois, dans le premier groupe, et à deux reprises aux âges de 4 et 6 mois, dans le deuxième groupe.

Le cuivre et le magnésium dans le sérum sanguin ont été déterminés aux âges de 4 mois dans le premier groupe, et 4 et 6 mois dans le deuxième groupe.

Le but de ce travail était de rechercher un rapport entre des caractères biochimiques du sang à différents âges et des caractéristiques de qualité de la viande de Porcs abattus à deux poids différents $(87$ et $101 \mathrm{~kg}$ ).

Les résultats obtenus permettent de tirer les conclusions suivantes:

1) la seule différence sexuelle observée portait sur l'état de rigor du jambon, avec un avantage en faveur des porcs mâles castrés;

2) les caractères sanguins qui se sont révélés les plus intéressants sont l'activité AspAT et les taux de $\mathrm{Cu}$ et $\mathrm{Mg}$ dans le sérum, et le taux de P.RNA dans les leucocytes, qui dès l'âge de 4 mois montrent des relations significatives avec les caractéristiques de qualité de la viande ;

3) une relation phénotypique n'autorise pas à affirmer qu'un caractère en influence un autre d'une façon définie. Des études sur un matériel animal plus important et le calcul des corrélations génétiques entre les indices biochimiques sanguins et les caractères de qualité de la viande sont donc nécessaires pour établir de façon plus certaine les relations rapportées ici. 


\section{References}

Davidson J.N., 1972. Biochimie des acides nucléiniques. PWRiL, Warszawa.

DeREVINSKIJ B.B., 1970. The activity of transaminases in blood serum in pigs of various breeds (rus.). Biologija, 5 (1), 100-103.

Duniec H., Rózycki M., Rózyczka J., Szewczyk A., 1975. Héritabilité du pH et de la couleur de la viande, et corrélations phénotypiques et génétiques avec les valeurs d'engraissement et de boucherie de Porcs des races Large White Polonaise et Landrace Polonaise (Pol.). Rocz. Nauk. roln., Seria B, 2, 59-71.

Ender K., Pfeiffer H., 1974. Untersuchungen zur züchterrischen Beeinflussung der Fleischbeschaffenheit beim Schwein auf der Grundlage von Ergebnissen aus Prüfstationen. 2 Mitt. Genetisch bedingte Differenzierung der Fleischbeschaffenheit. Arch. Tierz. Bd., 17 (4), 245-257.

Glen A.C.A., 1967. Measurement of DNA and RNA in human peripheral blood lymphocytes. Clin. Chem., 13, 299-313.

Guszkiewicz A., 1972. Levels of AspAT and ALAT aminotransferases, aldolase and phosphatase in blood serum of some breeds and crosses of cattle (pol.). PAN, Instytut Genetyki i Hodowli Zwierzat Jastrzebiec (doctoral dissertation).

Harris C., 1961. The lymphocytes like cell in the marrow of rats. Blood, 18, 691-701.

JANICKI M.A., 1970. Viande aqueuse, son importance et sa présence (pol.). Zesz. probl. Post. Nauk roln., 103, 13-20.

Koćwin M., 1974. Dynamique de la synthèse de RNA dans les leucocytes du sang périphérique des Porcs en fonction du sexe, de l'âge et de l'intensité de croissance (pol.). Zesz. Nauk AR w Szczecinie, 44, 51-60.

KoćwiN M., 1976. An interrelation between the level of ribonucleic acid in leucocytes and lymphocytes of blood, the fattening growth and meat utility of pigs. Theor. appl. Genet., 47, 87-95.

Koćwin M., PIECh H., 1978. Indices biochimiques du sang et valeurs d'exploitation des porcins. IV" partie : Etudes du rapport entre l'activité de GOT et GPT dans le sérum sanguin et indices de qualité de viande des Porcs (pol.). Zesz. Nauk. AR w Szczecinie, 69, 71-79.

Kolataj A., 1966. Physiological investigations on heterosis in chickens. II. - Transaminase GOT and GPT in blood plasma (pol.). Folia biol., 14, 459-499.

Mc Gloughlin P., Mc Gloughlin J.V., 1975. The heritability of $\mathrm{pH}$ in Longissimus dorsi muscle in Landrace and Large White pigs: Livest. Prod. Sci., 2 (3), 271-280.

Mudra A., 1958: Statistische Methoden für Landwirtschaftliche Vorsuche. Parey-BerlinHamburg.

Murray R.G., Murray A., 1961. Studies on the fate of lymphocytes labeling small thymic lymphocytes with tritiated tymidyne. Blood, 18, 737-749.

Ockerman H.W., Cahill V.R., 1969. Reflectance as a measure of pork and beef muscle tissue colour. J. anim. Sci., 28, 750-754.

Petrenko G.G., 1969. Content of nucleic acids in blood in pigs in dependence on age and intensity of growth (rus.). Vostnik. Sel. Chez. Nauk, 14, 79-81.

Reitman S., Frankel S., 1956. After Szczeklik E., 1973. Enzymologia kliniczna, 255-256 (pol.). PZWL Warszawa. Am. J. clin. Pathol., 28 (1), 56. 
Schmidt G., Tannhausser S.J., 1945. A method for the determination of desoxyribonucleic acid, ribonucleic acid and phosphoproteins in animal tissues. J. biol. Chem., 83, 161.

Sidor V., Kovac L., 1972. Histological structure of thyroid gland, its relation with the meat quality indices and some blood biochemical indices in Pietrain fattening pigs (czech.). Polnehospodarstvo. R., 18 (3), 228-238.

Suskov S., 1971. Variability at various age and correlation of enzymes of blood serum with morphological composition of pigs' carcass (czech.). Zb. Nauk. Rab. VIZ Dubrovicy, 24, 56-58.

SNedecor G.W., 1956. Statistical methods. 5th ed. Ames. Iowa State Univ. Press.

Tsanev R., Markov S.G., 1960. Substances interfering with spectrophotometric estimation of nucleic acids and their elimination by Twiwavelength method. Biochim. biophys. Acta, 42, 442 .

Walter Z., 1970. Chemical and physicochemical examinations of desoxyribonucleic acid in leucocytes (pol.). Qualifying thesis, University of Lódz.

Vos M.P.M., Sybesma W., 1971. Relation between meat quality of market pigs. II Inter. Symp. on condition and meat quality in pigs.

Zielinska M., 1973. Etudes sur le taux des acides nucléiques dans les leucocytes des bovins (pol.). Doc. thesis. Inst. Gen. i Hod. Zwierzat PAN, Jastrzebiec. 